\title{
The Effect Of Conference Call Initiations On Analyst Coverage And Institutional Ownership
}

\author{
Melita Stephanou-Charitou, University of Nicosia, Cyprus \\ Adamos Vlittis, University of Nicosia, Cyprus \\ Petros Lois, University of Nicosia, Cyprus
}

\begin{abstract}
The study empirically examines changes in institutional ownership and analyst coverage in the years following conference call initiations. We find significant increases in both variables in the years following initiations of conference calls after controlling for confounding factors. These results complement prior research on the benefits of disclosures and suggest that expanded disclosures create additional institutional and analyst interest in stocks.
\end{abstract}

Keywords: Voluntary disclosures, conference calls, institutional ownership, analyst coverage

\section{INTRODUCTION}

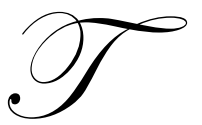

his study examines whether firms with improvements in voluntary disclosures experience increases in institutional interest and analyst coverage. Institutional investors and financial analysts play an important role in the capital markets and firms regard them a significant element for their success. Institutional investors are foremost a major source of capital but firms also consider them essential for creating a stable and informed shareholding that has a basic understanding of the company (e.g. Holland, 1998). Financial analysts produce, analyze and disseminate information about firms and contribute to the creation of more informative stock prices and higher stock liquidity. Analyst coverage has come into widespread use as a proxy for the richness of a firm's information environment (e.g. Lys and Soo, 1995; Brown and Higgins, 2002; Lang et al., 2003, Charitou and Karamanou, 2009).

Given the importance of financial analysts and institutional investors, it is imperative to investigate factors associated with their incentives to follow firms and more specifically the effect of disclosures on these incentives. Firms provide much of the information analysts and institutions use in their evaluations. Prior studies suggest that more informative disclosures affect intermediation for a firm's stock in the capital market by reducing information asymmetry (e.g. Barry and Brown 1984, 1985, Diamond and Verrecchia 1991; Kim and Verrecchia, 1994), lowering the cost of information acquisition (e.g. Bhushan, 1989a, 1989b; Lang and Lundhom, 1997), and increasing the firm's visibility (e.g. Merton, 1987; Fishman and Hagerty 1989).

However, ex-ante the relation between disclosures and intermediation is complex and ambiguous. For example, disclosures can pre-empt analysts' ability to distribute managers' private information to investors, leading to a decline in their demand. Also disclosures can reduce institutions' competitive advantage and potential for profitable trading opportunities, thereby diminishing incentives to invest in the firm. So, it is not obvious ex-ante that the relation between disclosures, analyst coverage and institutional ownership is positive.

We first investigate this relation by examining changes in institutional ownership and analyst coverage in the years following initiations of conference calls. Conference calls are ex-ante commitments to voluntary disclosure, and are interactive. That is, managers commit to quarterly meetings with analysts and institutions where they get the chance to elaborate on firm performance outside the normal accounting conventions, but most 
importantly get to answer questions from analysts and financial institutions. Both, institutions and analysts consider direct contacts with executives and spoken dialogue among the most important sources for financial information (AIMR, 2001).

In addition, we also examine the effect of regulation FD on this relation. Before regulation FD, the majority of conference calls in the sample restricted access to invited professionals ("closed" conference calls). Regulation FD, implemented in October of 2000, requires firms to make material disclosures broadly available and is likely to influence the effect of conference calls on analysts' coverage and institutional ownership. The direction of this effect, however, is ambiguous and depends on many factors, such as the effect of the regulation on the quality of information disclosed through conference calls, and the reaction of institutions and analysts to the regulation in terms of investments in private information acquisition. An unequivocal change is that, while before regulation FD analysts and institutions could maintain their information advantage over other investors, disclosures after the regulation reduce this competitive advantage and possibly their willingness to cover and/or invest in the company. The effect of the regulation on this relation is thus an empirical question. To shed light on this, we compare changes in analyst coverage and institutional ownership in the pre and post FD era.

The empirical evidence suggests that analyst coverage and institutional ownership increase in the years following initiations of conference calls. These findings complement similar evidence from prior studies that use alternative measures of disclosure. We find no significant evidence of a differential effect on this relation in the post-FD era.

Three prior studies use the summary AIMR ratings of firms' disclosures to document that more highlyrated disclosures are associated with greater analyst following (Lang and Lundholm,1996; Healy et al., 1999) and greater ownership by transient institutional investors (Bushee and Noe, 2000). However, the sample firms covered in these studies are already large and widely followed. A related problem with AIMR measures of disclosure is that it is difficult to precisely define the timing of any change in disclosure, making it difficult to infer whether disclosure changes followed or preceded changes in the variables of interest (Healy and Palepu, 2001). Conference calls, on the other hand, allow research on disclosure policies of small- and medium-sized firms in more recent years. Furthermore, the timing and initiation of conference calls is known, which makes it possible to perform powerful tests on changes in the variables of interest. The paper also differs from Francis et al. (1997) that examine the effect of analyst-initiated presentations on analyst following and forecast properties. In our study, conference calls are initiated by the firms and are targeted not only to analysts but also to institutional investors. So, firm-initiated conference calls are more likely to capture attempts to attract these individuals to the firm.

The paper contributes to literature on voluntary disclosures, analyst coverage and institution ownership. Bushman and Smith (2001) highlight the need to test hypotheses concerning differential economic effects of disclosures of various types. This paper shows that expanded disclosure, through conference calls, contributes to increases in institutional ownership and analyst coverage. Also, given the importance that firms place on analyst coverage and institutional ownership, incentives of analysts to follow firms and institutions to invest in firms is of primary interest to academics and practitioners. The study shows that analysts and institutions are attracted to firms with a higher quality of voluntary disclosures.

The remainder of the paper is organized as follows. In the next section we review related literature and introduce the hypotheses. Section 3 presents the empirical design and variable measurement. Sample selection and characteristics are presented in Section 4 and empirical results in Section 5. Section 6 concludes.

\section{PRIOR LITERATURE AND HYPOTHESIS DEVELOPMENT}

\section{Institutional Ownership and Disclosures}

As previously stated managers value institutional investors' interests and often use disclosures not only to increase the firm's visibility but also to signal the value of their firm, and increase institutional investors' confidence in the firm's strategy (Holland,1998). Close relations with institutional investors enable managers to create a stable and informed shareholding, and ensure that major investors have a basic understanding of the company (and are not 
surprised by events or news affecting the company). A NIRI survey in 1996 indicated that conference calls in particular, were targeted not only to current institutional investors but also to potential institutional investors. From a sample of 147 conference call companies, 77\% invited potential institutional investors to listen to the conference call.

Corporate disclosure practices are likely to influence institutional investors for a number of reasons. Diamond and Verrechia (1991) show that a high level of disclosures reduces information asymmetry between insiders and outsiders, which improves liquidity and lessens the price impact of large trades. Improved liquidity is likely to attract institutional investors' interests since they tend to prefer firms with a greater trading volume and higher liquidity (Gompers and Metrick, 1998). Institutional investors could also be sensitive to corporate disclosure practices if disclosure enables them to evaluate and analyze a firm's performance more effectively and increase their potential for profitable trading opportunities (Bushee and Noe, 2000). Finally, disclosure practices are important to active institutional investors if they rely on that information for corporate governance activities (Karamanou and Vafeas, 2005; Ajinkya et al., 2005). Bushman et al. (2004) argue that information is a critical part of effective corporate governance mechanisms. Active institutional investors are therefore more likely to follow firms which are more transparent and committed to more forthcoming disclosures.

Prior research finds that institutions prefer firms with higher quality disclosures. Healy et al. (1999) and Bushee and Noe (2000) documented that firms which expanded voluntary disclosures, as measured by increases in analyst disclosure ratings (AIMR scores), experienced increases in institutional ownership. Drawing on this, we expect initiations of conference calls to have a positive impact on institutional ownership:

Hypothesis 1a: Institutional ownership increases in the years following initiation of conference calls.

Disclosure could, however, also erode profit opportunities if it substitutes for private information collection. In October, 2000 the SEC passed regulation FD that prohibits firms from disclosing material information to a select group of participants without simultaneously disclosing the same information to the public. It is plausible that regulation FD has an effect on the relation between conference calls and institutional investors. However, this effect is likely to depend on many factors. For example, assuming that regulation FD has its intended effect of "leveling the playing field" without compromising the quality of disclosed information, then the effect of regulation FD on institutions will depend on the source of their competitive advantage. If disclosures through conference calls substitute for private information collection then institutions loose a competitive advantage and will have lesser incentives to invest. However, if their competitive advantage is derived from their superior ability to interpret public information then the regulation should have no effect on institutional investors. Complicating things further, is the ambiguous effect of the regulation on the information flow to the market place. There is an ongoing debate on the effect of regulation FD on the quality of information disclosed, with some arguing for a chilling of the information flow (e.g. Duarte et al.,2007) and others arguing for improvements or no change in the information flow (e.g. Heflin et al., 2003). Thus, stated in its null form the hypothesis is:

Hypothesis 1b: Regulation FD has no effect on institutional ownership in the years following initiations of conference calls.

\section{Analyst Coverage and Disclosures}

As with institutional investors, managers appear to value analyst coverage and try to attract analysts to the firm. The relation between analyst coverage and firm disclosures mainly depends on how disclosures provided by firms affect the supply and demand for analyst services (Bushan, 1989b; Lang and Lundhold, 1996).

Disclosures provided by firms usually lower the cost of information acquisition by analysts and hence increases their supply. Thus, ceteris paribus, an increase in firm disclosures is expected to increase analyst coverage. The effect of firm disclosures on the demand for analyst services depends on whether analysts are primarily information providers or information intermediaries (Lang and Lundholm, 1996). If analysts are primarily information providers then firm disclosures could pre-empt (substitute for) the analyst report and hence decrease the demand for their services. If, on the other hand, analysts are primarily information intermediaries then firm 
disclosure complements the analyst report, enables analysts to create valuable new information and hence increases demand for their services.

In sum, ex-ante, the effect of firm disclosure on analyst coverage depends on their net effect on the aggregate supply and demand curves for analyst services. Nevertheless, extant limited prior research on this area showed that analysts and firm disclosure are complements but and not substitutes. Healy et al. (1999) document increased analyst coverage in firms with expanded voluntary disclosures and Lang and Lundholm (1993) find that firms with more informative disclosures have higher analyst coverage. Consistent with these findings, the analyst community appears to value firm provided disclosures in general and conference calls in particular. In an AIMR survey (AIMR, 2000), portfolio managers and investment analysts ranked spoken dialogue with company executives, analysts' conferences and conference calls to be among the most important sources of financial or corporate information. Drawing on the above, we expect initiations of conference calls to have a positive impact on analyst coverage. This hypothesis is formalized below:

Hypothesis 2a: Analyst coverage increases in the years following initiations of conference calls.

Regulation FD is also likely to have an impact on the demand and supply for analyst services. As discussed above, the direction of the impact depends on the effect of regulation FD on the quality of information disclosed through conference calls, but also on whether analysts are primarily information providers or intermediaries. The regulation is also likely to have a differential effect on analysts depending on brokerage house affiliation and their relation with managers (e.g. Gintschel and Markov, 2004). Based on the aforementioned discussion, we form the following hypothesis:

Hypothesis 2b: Regulation FD has no effect on analyst coverage in the years following initiations of conference calls.

\section{EMPIRICAL DESIGN AND VARIABLE MEASUREMENT}

We used time-series analysis to test our hypotheses. One of the advantages of a temporal analysis is that by using each firm as its own control over time, it allows for the control of firm-specific characteristics which are constant over time and helps isolate the effect related to the event. In the models to be estimated, each dependent variable is modeled as depending on company fixed effects, a set of conference call dummies and a set of controls:

$$
\begin{aligned}
& \text { Institutioal Ownership }=\alpha_{0}+\alpha_{1} \mathrm{f}_{\mathrm{i}}+\alpha_{2} \mathrm{Ccall}_{\mathrm{it}}^{0-2}+\alpha_{3} \mathrm{Ccall}_{\mathrm{it}}^{0-2} * \mathrm{FD}_{\mathrm{i}}+\alpha_{4} \mathrm{ROA}_{\mathrm{it}}+\alpha_{5} \log \left(\text { volum }_{\mathrm{it}}\right. \\
& +\alpha_{6} \log (\mathrm{MV})_{1 \mathrm{t}}+\alpha_{7} \log (\text { Std Returns })_{\mathrm{t}}+\alpha_{8} \text { Leverag }_{\mathrm{G}_{\mathrm{t}}}+\alpha_{9} \mathrm{~S} \& \mathrm{P} 50 q_{\mathrm{t}} \\
& +\alpha_{10} \text { Div.Yield }_{\mathrm{t}}+\alpha_{11} \text { Price/Earning }_{\mathrm{S}_{\mathrm{t}}}+\alpha_{12} \text { BooktoMarket }_{\mathrm{it}} \\
& +\alpha_{13} \text { Salesgrowth }_{\mathrm{t}}+\varepsilon_{\mathrm{it}} \\
& +\beta_{6} \log (\mathrm{MV})_{\text {it }}+\beta_{7} \log (\operatorname{Std} \text { Ret })_{\mathrm{it}}+\beta_{8} \text { Std.ROA }_{\mathrm{it}}+\beta_{9} \text { No.Segments }_{\mathrm{it}}+\beta_{10} \text { Price }_{\mathrm{it}} \\
& +\beta_{11} \mathrm{~S} \& \mathrm{P} 509_{\mathrm{t}}+\beta_{12} \text { Div. Yield }_{\mathrm{t}}+\beta_{13} \text { Price/Earing }_{\mathrm{St}}+\beta_{14} \text { Book toMarket }_{\mathrm{it}} \\
& +\beta_{15} \text { Sales Growth }_{\mathrm{t}}+\eta_{\mathrm{it}}
\end{aligned}
$$

where $f_{i}$ denotes a company's fixed effect, Ccallit ${ }_{i t}^{0-2}$ is a dummy variable corresponding to the years after initiation of conference calls, and $\mathrm{FD}_{\mathrm{i}}$ is a dummy variable intended to capture the effect of regulation FD.

The primary coefficients of interest are $\alpha_{2}$ and $\beta_{2}$. Positive and statistically significant coefficients would indicate that firms show larger improvements in institutional ownership and analyst coverage in the years following initiations of conference calls than the years prior to conference call initiations. Coefficients $\alpha_{3}$ and $\beta_{3}$ show differences in the two test variables in the post-FD era versus the pre-FD era. Positive coefficients would indicate larger improvements in the test variables following initiations of conference calls in the post-FD era and negative 
coefficients would indicate a lesser improvement in the post-FD era.

We follow prior research to include a large number of control variables that were shown to be associated with disclosure quality, institutional ownership and analyst following. For the institutional ownership model we mostly follow Bushee and Noe (2000). We use returns on assets, measured as net income before extraordinary items to total assets, to proxy for firm performance which has been shown to be positively associated with institutional ownership and disclosure quality. The natural logarithm of average monthly dollar volume over the fiscal year captures institutional preferences for more liquid stocks. The natural logarithm of market value controls for size. We include leverage, measured as long-term debt to total assets, and the natural logarithm of standard deviation of monthly returns to proxy for different dimensions of risk. Higher financial leverage was shown to be associated with higher levels of institutional ownership, while higher levels of idiosyncratic risk are associated with lower levels of institutional ownership (Bushee and Noe, 2000). We control for institutional preferences for firms listed in the S\&P 500 index by including an indicator variable that takes the value of " 1 " if the firm is listed in the S\&P 500 index and zero otherwise.

In the analyst coverage specification we use a number of controls to proxy for analysts' incentives to follow the firm. The natural logarithm of average monthly dollar volume over the fiscal year and the market value of equity issued proxy for potential underwriting revenues (Bricker et al., 1999). Firm size, measured as the logarithm of the market value of equity, is used to proxy for potential analyst revenue and demand for analyst services (Bushan, 1999a; O’Brien and Bushan, 1990; Brennan and Hughes ,1991; Lang and Lundholm, 1993). Most studies find that analysts tend to prefer lower risk firms whose earnings are more predictable. We use the standard deviation of returns, the standard deviation of return on assets and the number of business segments to proxy for different dimensions of risk and firm complexity. The closing stock price at fiscal year end is used to proxy for analysts' preference for low-priced stocks due to proportionally higher brokerage commissions (Brennan and Hughes, 1991). We control for analysts' preference for firms listed in the S\&P 500 index by including an indicator variable that takes the value of " 1 " if the firm is listed in the S\&P 500 index and zero otherwise.

Finally, in both models we include dividend yield, price-earnings ratio, book to market ratio and sales growth to capture changes in fundamentals that can simultaneously affect changes in disclosure quality, analyst coverage and institutional ownership (Bushee and Noe, 2000; Bushee, 2001).

Models (1) and (2) are estimated using fixed effects regressions. In addition, both models are estimated using changes specification in order to strengthen the empirical findings and mitigate the potential for omitted variable bias.

\section{SAMPLE SELECTION AND CHARACTERISTICS}

Conference call data are identified from Thomson Financial First Call, an information provider to institutional investors. First Call maintains a dataset of daily conference call schedules from 1995 to 2004, which we used to identify firms hosting conference calls. The initiation year of conference calls is the earliest year a firm appears in the database. Institutional holdings are obtained from Spectrum. Analyst coverage is the number of analysts with at least one earnings forecast in the $\mathrm{I} / \mathrm{B} / \mathrm{E} / \mathrm{S}$ dataset during the fiscal year. Control variables on volume, stock price and returns are obtained from CRSP and control variables on financial information are obtained from Compustat.

All variables in the analysis are industry adjusted except the indicator variable for whether the firm is included in the S\&P 500 index. Industry adjusted values are estimated for each firm-year as the difference between the sample firm's value and the median value for firms in the same 4-digit SIC code in the same fiscal yearii ${ }^{\text {ii }}$ Firms with less than five peers in the same SIC industry classification code and firms with negative book value of equity are excluded from the sample. Firms included in the sample must have at least one quarterly conference call a year in the two years following initiation of conference calls. Firms with missing observations on any of the control variables are excluded from the sample. As a final screening requirement, sample firms must have available data in the year prior to conference call initiation. 
Table I-Panel A: Time Distribution of the 2399 Conference Call Initiations Occurring between 1995 and 2002

\begin{tabular}{|l|c|c|c|c|c|c|c|c|c|}
\hline Year & $\mathbf{1 9 9 5}$ & $\mathbf{1 9 9 6}$ & $\mathbf{1 9 9 7}$ & $\mathbf{1 9 9 8}$ & $\mathbf{1 9 9 9}$ & $\mathbf{2 0 0 0}$ & $\mathbf{2 0 0 1}$ & $\mathbf{2 0 0 2}$ & Total \\
\hline $\mathrm{N}$ & 499 & 394 & 301 & 295 & 307 & 312 & 261 & 30 & 2399 \\
\hline Pct. Sample & $20.80 \%$ & $16.42 \%$ & $12.55 \%$ & $12.30 \%$ & $12.80 \%$ & $13.01 \%$ & $10.88 \%$ & $1.25 \%$ & $100.00 \%$ \\
\hline
\end{tabular}

Table I-Panel B: Industry Distribution of the 3488 Conference Call Initiations 1995 and 2002

\begin{tabular}{|c|c|c|c|}
\hline 2-digit SIC & Industry Description & Number & Pct. of Sample \\
\hline 10 & Metal Mining & 19 & $0.79 \%$ \\
\hline 13 & Oil and Gas Extraction & 72 & $3.00 \%$ \\
\hline 15 & Bldg Cnstr-Gen Contr, Op Bldr & 17 & $0.71 \%$ \\
\hline 20 & Food and Kindred Products & 29 & $1.21 \%$ \\
\hline 22 & Textile Mill Products & 16 & $0.67 \%$ \\
\hline 23 & Apparel and Other Finished Pds & 22 & $0.92 \%$ \\
\hline 24 & Lumber and Wood Pds, Ex Furn & 11 & $0.46 \%$ \\
\hline 25 & Furniture and Fixtures & 15 & $0.63 \%$ \\
\hline 26 & Paper and Allied Products & 25 & $1.04 \%$ \\
\hline 27 & Printing, Publishing and Allied & 33 & $1.38 \%$ \\
\hline 28 & Chemicals and Allied Products & 188 & $7.84 \%$ \\
\hline 29 & Petroleum Refining and Related Inds & 14 & $0.58 \%$ \\
\hline 30 & Rubber and Misc Plastics Prods & 19 & $0.79 \%$ \\
\hline 31 & Leather and Leather Products & 12 & $0.50 \%$ \\
\hline 33 & Primary Metal Industries & 33 & $1.38 \%$ \\
\hline 34 & Fabr Metal, Ex Machy, Trans Eq & 28 & $1.17 \%$ \\
\hline 35 & Indl, Comml Machy, Computer Eq & 163 & $6.79 \%$ \\
\hline 36 & Electr, Oth Elec Eq, Ex Cmp & 214 & $8.92 \%$ \\
\hline 37 & Transportation Equipment & 49 & $2.04 \%$ \\
\hline 38 & Meas Instr;Photo Gds;Watches & 161 & $6.71 \%$ \\
\hline 39 & Misc Manufacturng Industries & 20 & $0.83 \%$ \\
\hline 42 & Motor Freight Trans, Warehous & 10 & $0.42 \%$ \\
\hline 44 & Water Transportation & 10 & $0.42 \%$ \\
\hline 45 & Transportation By Air & 10 & $0.42 \%$ \\
\hline 48 & Communications & 65 & $2.71 \%$ \\
\hline 49 & Electric, Gas, Sanitary Serv & 61 & $2.54 \%$ \\
\hline 50 & Durable Goods-Wholesale & 52 & $2.17 \%$ \\
\hline 51 & Nondurable Goods-Wholesale & 29 & $1.21 \%$ \\
\hline 53 & General Merchandise Stores & 12 & $0.50 \%$ \\
\hline 56 & Apparel and Accessory Stores & 29 & $1.21 \%$ \\
\hline 57 & Home Furniture and Equip Store & 13 & $0.54 \%$ \\
\hline 58 & Eating and Drinking Places & 31 & $1.29 \%$ \\
\hline 59 & Miscellaneous Retail & 46 & $1.92 \%$ \\
\hline 60 & Depository Institutions & 113 & $4.71 \%$ \\
\hline 61 & Nondepository Credit Institutions & 23 & $0.96 \%$ \\
\hline 62 & Security and Commodity Brokers & 18 & $0.75 \%$ \\
\hline 63 & Insurance Carriers & 71 & $2.96 \%$ \\
\hline 64 & Insurance Agents, Brokers and Service & 11 & $0.46 \%$ \\
\hline 65 & Real Estate & 12 & $0.50 \%$ \\
\hline 67 & Holding, Other Invest Offices & 95 & $3.96 \%$ \\
\hline 73 & Business Services & 325 & $13.55 \%$ \\
\hline 78 & Motion Pictures & 10 & $0.42 \%$ \\
\hline 79 & Amusement and Recreation Svcs & 18 & $0.75 \%$ \\
\hline 80 & Health Services & 33 & $1.38 \%$ \\
\hline \multirow[t]{2}{*}{87} & Engr, Acc, Resh, Mgmt, Rel Sves & 40 & $1.67 \%$ \\
\hline & Other & 102 & $4.25 \%$ \\
\hline Total & & 2399 & $100.00 \%$ \\
\hline
\end{tabular}


The final sample consists of 2,399 unique firms and 12,661 firm-year observations. Table I presents the industry and time distribution of the sample firms. The sample covers a large number of industries with the largest concentration in the business services industry (2-digit SIC 73), 325 firms in this industry initiate conference calls during the sample period, followed by the electrical equipment industry (2-digit SIC 36) with 214 firms and the chemical products industry (2-digit SIC 28) with 188 firms. It is noteworthy that these industries are usually classified as high technology industries with high uncertainty and growth and less informative financial statements. So, consistent with Tasker (1998a) these firms are more likely to be in need of conference calls in order to complement their less informative financial statements. The distribution of conference call initiations across time is almost uniform except for the year 2002 with only 30 initiations. This is mostly due to sample restrictions since we require sample firms to have conference calls in the two years following the year of initiation.

We initially compare the sample firms on selected ratios before and after the initiation of conference calls using the parametric t-test and the non-parametric Wilcoxon signed-ranks matched-pairs test. The results are presented in table II. For ease of interpretation we present statistics on the unadjusted variables in this table. Results in this table suggest that there is a significant increase in both institutional ownership and analyst coverage in the three years following initiation of conference calls as compared with the three years prior to initiation. Institutional ownership averages $41 \%$ after initiation as compared to $35 \%$ before the initiation of conference calls. Analyst coverage averages 6.9 after initiation and 6.3 in the years before initiation of conference calls. Both results are consistent with the hypotheses of this study. Results in table also suggest that sample firms experience a decline in growth following initiations of conference calls. This is indicated by the significant decrease in dividend yield, price to earnings and sales growth and from the significant increase in book to market ratio as compared to the three years prior to conference call initiations. The underlying change in fundamentals suggests that it is important to control for these variables in the multivariate analysis in order to isolate the effect of conference calls.

Table II reports descriptive statistics for the sample firms. For each variable the mean (median) is presented in the top (bottom) row. The "after" column presents the averages for the three years following initiation of conference calls and the "before" column presents the averages for the three years before initiation. Institutional ownership is the quarterly average percentage of institutional holdings during the fiscal year. Analyst coverage is the number of analysts with at least one earnings forecast in the I/B/E/S dataset during the fiscal year Div. yield is the ratio of dividends (CS\#21) to market value of equity (CS\#24 $\square$ CS\#25). Price/earnings is the ratio of market value of equity (CS\#24*CS\#25) to income before extraordinary items (CS\#18). Book to market is the ratio of book value of equity (CS\#60) to market value of equity (CS\#24*CS\#25). Sales growth is the percentage change in annual sales (CS\#12). All variables are winsorized at $2 \%$ and $98 \%$ to avoid the effect of outliers.

Table II: Descriptive Statistics

\begin{tabular}{|l|c|c|c|c|c|}
\hline Variable & After $\mathbf{( N = 6 8 6 0 )}$ & Before $(\mathbf{N}=\mathbf{5 4 0 3})$ & Difference & t-value & Wilcoxon \\
\hline Institutional Ownership & 0.411 & 0.355 & 0.056 & 13.29 & -12.83 \\
\hline & 0.412 & 0.333 & 0.079 & & \\
\hline Analyst Coverage & 6.954 & 6.350 & 0.604 & 4.91 & -11.67 \\
\hline & 5.000 & 4.000 & 1.000 & & \\
\hline Div. Yield & 0.010 & 0.012 & -0.002 & -5.70 & 7.27 \\
\hline & 0.000 & 0.000 & 0.000 & & \\
\hline Price/Earnings & 15.872 & 17.140 & -1.268 & -1.61 & 5.38 \\
\hline & 14.455 & 15.670 & -1.215 & & \\
\hline Book to Market & 0.602 & 0.500 & 0.102 & 12.43 & -7.99 \\
\hline & 0.465 & 0.422 & 0.043 & & \\
\hline Sales Growth & 0.274 & 0.574 & -0.301 & -10.56 & 6.74 \\
\hline
\end{tabular}

\section{EMPIRICAL RESULTS}

\section{Univariate Analysis}

In table III we present mean and median industry-adjusted institutional ownership and analyst coverage during the event years -3 to 2 . Both a t-test and a Wilcoxon signed-ranks test are used to assess whether the variables 
are significantly different from zero in the event years and whether there is a significant difference in the pre- and post-initiation period. Throughout the event period sample firms have significantly higher institutional ownership and analyst coverage compared to their industry peers. The mean (median) industry-adjusted institutional ownership is $9 \%(6 \%)$ in the pre-initiation year and $13 \%(11 \%)$ in the post-initiation year. Consistent with prior research, this finding suggests that conference calls are initiated not only to attract new institutional investors but also as a response to pressure from existing institutions to provide more information (e.g. Ajinkya et al., 2005). More importantly, results in table II indicate that there is a significant increase in institutional ownership in the years following the initiation of conference calls. The mean (median) difference between the pre-initiation period $(-3,-1)$ and the post-initiation period $(0,2)$ is $4 \%(5 \%)$ and it is statistically significant at the 0.001 level.

Analyst coverage presents a similar pattern. The mean (median) industry-adjusted analyst coverage is 5.3 (3) in the pre-initiation period and 5.5 (4) in the post-initiation period. The mean (median) difference between the pre- and post-initiation period is 0.24 (1) and is statistically significant at the 0.1 level using a t-test and at the 0.001 using Wilcoxon signed-ranks test, two-tailed. Notwithstanding, the weaker pattern of analyst coverage, evidence suggests that both pressure from existing analysts and attempts to attract new analysts are partly behind conference call initiations.

Overall, the evidence presented in this table is consistent with significant increases in institutional ownership and analyst coverage following initiations of conference calls. However, the findings should be interpreted with caution because these tests do not control for contemporaneous changes in other factors that may affect the variables of interest.

A t-test and Wincoxon signed rank test are used to test whether there is a significant change in the mean and median for sample firms in the years of the disclosure increase (years 0 to 2 ) relative to the pre-event period (years -3 to -1 ). \# and \& indicate level of significance at the $1 \%$ and $10 \%$ levels, respectively (Table III).

Table III: Industry Adjusted Institutional Ownership and Analyst Coverage around Initiations of Conference Calls

\begin{tabular}{|c|c|c|c|c|c|c|c|c|c|c|}
\hline & \multicolumn{6}{|c|}{ Year Relative to Event } & Pre-Initiation & Post-Initiation & Difference \\
\hline & & -3 & -2 & -1 & 0 & 1 & 2 & $(-3,-1)$ & $(0,2)$ & \\
\hline \multirow{3}{*}{$\begin{array}{l}\text { Institutional } \\
\text { Ownership }\end{array}$} & Mean & $0.1^{\#}$ & $0.1^{\#}$ & $0.08^{\#}$ & $0.11^{\#}$ & $0.13^{\#}$ & $0.14^{\#}$ & $0.09^{\#}$ & $0.13^{\#}$ & $-0.04^{\#}$ \\
\hline & Median & $0.07^{\#}$ & $0.06^{\#}$ & $0.04^{\#}$ & $0.09^{\#}$ & $0.12^{\#}$ & $0.13^{\#}$ & $0.06^{\#}$ & $0.11^{\#}$ & $-0.05^{\#}$ \\
\hline & $\mathrm{N}$ & 1362 & 1642 & 2399 & 2399 & 2281 & 2180 & 5403 & 6860 & \\
\hline & & \multicolumn{6}{|c|}{ Year Relative to Event } & Pre-Initiation & Post-Initiation & Difference \\
\hline & & -3 & -2 & -1 & $\mathbf{0}$ & 1 & 2 & $(-3,-1)$ & $(0,2)$ & \\
\hline \multirow{3}{*}{$\begin{array}{l}\text { Analyst } \\
\text { Coverage }\end{array}$} & Mean & $5.99^{\#}$ & $5.61^{\#}$ & $4.70^{\#}$ & $5.40^{\#}$ & $5.62^{\#}$ & $5.61^{\#}$ & $5.30^{\#}$ & $5.54^{\#}$ & $-0.24^{\&}$ \\
\hline & Median & $3.00^{\#}$ & $3.00^{\#}$ & $2.00^{\#}$ & $3.50^{\#}$ & $4.00^{\#}$ & $4.00^{\#}$ & $3.00^{\#}$ & $4.00^{\#}$ & $-1.00^{\#}$ \\
\hline & $\mathrm{N}$ & 1362 & 1642 & 2399 & 2399 & 2281 & 2180 & 5403 & 6860 & \\
\hline
\end{tabular}

\section{Multivariate Analysis}

In table IV we present multivariate results. Models (1) and (2) are estimated using a fixed effects regression controlling for other factors that may affect the variables of interest. Model (1) explains roughly $85 \%$ of the variation of industry-adjusted institutional ownership and is highly significant. Significant $\alpha_{2}$ coefficient indicates significant increases in institutional ownership in the years following conference call initiation. Consistent with the univariate findings in table III, these results suggest that conference calls attract institutional interest. Regulation FD does not appear to have any effect on this relation. Coefficient $\alpha_{3}$ is not significantly different from zero suggesting that the relation between conference calls and institutional ownership does not change in the post-regulation FD environment.

Control variables are generally consistent with prior research. The coefficient on return on assets is negative and significant at $\mathrm{p}<0.1$ indicating that institutions prefer firms with recent poor performance. The coefficients on market value of equity and dollar volume are both positive and statistically significant capturing institutional investors' preferences for larger firms with higher levels of trading volume. Institutional investors 
prefer firms with less idiosyncratic risk as indicated by the significant negative coefficient on the standard deviation of returns. Finally, institutional ownership is negatively correlated with dividend yield and sales growth and positively correlated with price to earnings and book to market.

Model (2) explains $90 \%$ of the variation of industry-adjusted analyst coverage and is highly significant. The significant $\beta_{2}$ coefficient indicates a significant increase in analyst coverage in the years following initiation of conference calls. Similar to the institutional ownership model, coefficient $\beta_{3}$ is not statistically significant, indicating that regulation FD has no effect on this relation. Overall, our evidence implies that firm disclosures and information production by analysts are complements, thus supporting similar findings by prior studies (Lang and Lundholm, 1996; Healy et al., 1999).

Control variables are consistent with our expectations. Analysts prefer to follow larger firms, and firms with higher market value of trading volume, partially due to higher underwriting fees. Also, analysts prefer to follow firms with less uncertainty and firms with more predictable earnings as indicated by the significant negative coefficients on the standard deviation of returns and the standard deviation of return on assets. The coefficient on stock price is negative and significant capturing analysts' preferences for low priced stocks. More analysts follow firms listed on the S\&P 500 index and firms with higher book-to-market ratio. Finally, analyst coverage is negatively correlated with abnormally high sales growth probably due to higher uncertainty in these firms.

In columns 2 and 4 of table IV the analysis is performed using changes specifications. In the changes regressions all variables except the dummy variables are changes from the previous year. Results from these regressions are generally consistent with the results from the fixed effects models. The models explain roughly $15 \%$ and $12 \%$ of the variation of industry adjusted changes in institutional ownership and analyst coverage, respectively. In both models there is a significant increase in the changes of institutional ownership and analyst coverage following initiation of conference calls. Overall, the results presented in table IV are consistent with our hypotheses and suggest that institutional ownership and analyst coverage increase following initiations of conference calls.

Table IV reports estimates of the effect of conference call initiations on institutional ownership and analyst coverage. For each dependent variable we provide results for both fixed effects regression and changes regression. In the changes regressions all variables except the dummy variables are changes from the previous year. Institutional ownership is the quarterly average percentage of institutional holdings during the fiscal year. Analyst coverage is the number of analysts with at least one earnings forecast in the $\mathrm{I} / \mathrm{B} / \mathrm{E} / \mathrm{S}$ dataset during the fiscal year. Ccall ${ }^{0-2}$ is a dummy variable capturing the three years following initiation of conference calls (one in the three years after initiation and zero otherwise). FD is a dummy variable capturing the effect of regulation FD (one if the fiscal year is after the regulation and zero otherwise). ROA is the ratio of net income before extraordinary items (CS\# 8 ) to total assets (CS\#6). Volume is the market value of average monthly traded volume. Issue is the market value of equity (CS\#108) issued over the fiscal year. Market value is the market value of the firm at fiscal end (CS\#25*CS\#199). Std Returns is the standard deviation of monthly returns over the fiscal year. Leverage is the ratio of long-term debt (CS\#9) to total assets (CS \#6). Std Roa is the standard deviation of returns on assets for the 12 quarters prior to the fiscal year end (CS\#18/CS\#6). No. Segments is the number of business segments the firm operates in. Price is the closing price at fiscal yearend (CS\#199). S\&P 500 is an indicator variable that takes the value of one if the firm is listed in the S\&P 500 and zero otherwise. Div. yield is the ratio of dividends (CS\#21) to market value of equity

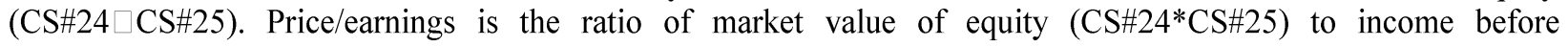
extraordinary items (CS\#18). Book to market is the ratio of book value of equity (CS\#60) to market value of equity (CS\#24*CS\#25). Sales growth is the percentage change in annual sales (CS\#12). All variables are industry adjusted by the same 4-digit SIC code except for the dummy variables. Fiscal year dummies are included in all regressions but the coefficients are not reported for brevity. Levels of significance are indicated by $* * *, * *, *$ for $1 \%, 5 \%$, and $10 \%$, respectively. All variables are winsorized at $2 \%$ and $98 \%$ to avoid the effect of outliers. 
Table IV: Regressions of Institutional Ownership and Analyst Coverage on Conference Call Time Dummies

\begin{tabular}{|c|c|c|c|c|}
\hline & \multicolumn{2}{|c|}{ Institutional Ownership } & \multicolumn{2}{|c|}{ Number of Analysts } \\
\hline & Fixed Effects & Changes & Fixed Effects & Changes \\
\hline \multirow[t]{2}{*}{ Intercept } & & -0.007 & & -0.534 \\
\hline & & $(-0.30)$ & & $(-1.22)$ \\
\hline \multirow[t]{2}{*}{$\mathrm{Ccall}^{0-2}$} & 0.020 & 0.018 & 0.689 & 0.195 \\
\hline & $(5.54) * * *$ & $(6.30) * * *$ & $(7.86)^{* * *}$ & $(3.49) * * *$ \\
\hline \multirow[t]{2}{*}{ Ccall $^{0-2} * \mathrm{FD}$} & -0.002 & -0.003 & 0.032 & 0.052 \\
\hline & $(-0.34)$ & $(-0.39)$ & $(0.20)$ & $(0.36)$ \\
\hline \multirow[t]{2}{*}{ ROA } & -0.015 & 0.015 & & \\
\hline & $(-1.89)^{*}$ & $(2.23)^{* *}$ & & \\
\hline \multirow[t]{2}{*}{ Log(volume) } & 0.027 & 0.028 & 0.613 & 0.473 \\
\hline & $(18.70)^{* * *}$ & $(22.03) * * *$ & $(17.87)^{* * *}$ & $(18.23)^{* * *}$ \\
\hline \multirow[t]{2}{*}{ Log (issue) } & & & -0.160 & -0.086 \\
\hline & & & $(-8.14) * * *$ & $(-6.35)^{* * *}$ \\
\hline \multirow[t]{2}{*}{$\log (\mathrm{MV})$} & 0.047 & 0.034 & 0.733 & 0.688 \\
\hline & $(20.11)^{* * *}$ & $(17.18)^{* * *}$ & $(12.72)^{* * *}$ & $(16.33) * * *$ \\
\hline \multirow[t]{2}{*}{ Log(std. returns) } & -0.019 & -0.016 & -0.174 & -0.177 \\
\hline & $(-5.96) * * *$ & $(-6.20) * * *$ & $(-2.40) * *$ & $(-3.52) * * *$ \\
\hline \multirow[t]{2}{*}{ Leverage } & 0.003 & 0.023 & & \\
\hline & $(0.28)$ & $(2.00)^{* * *}$ & & \\
\hline \multirow[t]{2}{*}{ Std. ROA } & & & -1.781 & -4.095 \\
\hline & & & $(-2.55) * *$ & $(-5.38) * * *$ \\
\hline \multirow[t]{2}{*}{ No. Segments } & & & -0.001 & 0.039 \\
\hline & & & $(-0.03)$ & $(1.31)$ \\
\hline \multirow[t]{2}{*}{ Stock Price } & & & -0.013 & -0.006 \\
\hline & & & $(-4.64) * * *$ & $(-2.90)^{* * *}$ \\
\hline \multirow[t]{2}{*}{ S\&P 500} & -0.047 & -0.010 & 1.535 & -0.379 \\
\hline & $(-4.49) * * *$ & $(-2.96) * * *$ & $(6.20) * * *$ & $(-5.66) * * *$ \\
\hline \multirow[t]{2}{*}{ Div. Yield } & -0.402 & -0.490 & 2.098 & 7.264 \\
\hline & $(-3.05) * * *$ & $(-3.62) * * *$ & $(0.67)$ & $(2.68) * * *$ \\
\hline \multirow[t]{2}{*}{ Price/Earnings } & 0.000 & 0.000 & 0.001 & 0.000 \\
\hline & $(2.27)^{* *}$ & $(0.38)$ & $(1.36)$ & $(1.12)$ \\
\hline \multirow[t]{2}{*}{ Book to Market } & 0.021 & 0.020 & 0.574 & 0.570 \\
\hline & $(5.96) * * *$ & $(5.96) * * *$ & $(6.91)^{* * *}$ & $(8.60) * * *$ \\
\hline \multirow[t]{2}{*}{ Sales Growth } & -0.002 & 0.000 & -0.106 & -0.002 \\
\hline & $(-3.42) * * *$ & $(-3.73) * * *$ & $(-6.35) * * *$ & $(-0.90)$ \\
\hline Fiscal Year Dummies & Included & Included & Include & Included \\
\hline F-Statistic & 24.82 & 81.53 & 40.40 & 62.37 \\
\hline R-square & $85.93 \%$ & $15.07 \%$ & $90.87 \%$ & $12.82 \%$ \\
\hline $\mathrm{N}$ & 12261 & 11053 & 12261 & 11053 \\
\hline
\end{tabular}

\section{Robustness Tests}

We conduct several robustness tests to increase confidence in our findings. Alternatively, the models are estimated using a balance panel of 1,230 unique firms with available information in all six years in the event period. Results are generally unchanged for institutional ownership but there is no evidence of a differential effect for analysts. It is worth noting that in the balanced panel the sample firms are larger by construction (due to survivorship bias). Given the richness of the information environment in larger firms, the marginal impact of an increase in disclosure may not be large enough to attract additional analyst interest.

To investigate the difference between firms that regularly conduct conference calls and those that do not, we repeated the empirical analysis on a sample of firms that conducted conference calls for only the year of initiation. The empirical evidence on institutional ownership and analyst coverage did not hold for these firms, indicating that the commitment to regular conference calls is the driving force behind the findings. 
As a final robustness test, models (1) and (2) are estimated using a simultaneous equation analysis where analyst coverage enters the institutional ownership equation and vice-versa. The simultaneous equation analysis is intended to account for the inter-relation between analysts and institutions and thus control for simultaneity bias (Ackert and Athanasakos, 2003; O'Brien and Bhushan, 1990). Results from the simultaneous equation analysis are generally consistent with the results from both the fixed effects and changes models.

\section{CONCLUSIONS}

The study presents an empirical analysis of the relation between institutional ownership, analyst coverage and voluntary disclosures. The findings suggest that institutional ownership and analyst coverage increase in the years following initiations of conference calls, after controlling for confounding effects. The evidence complements prior research on the consequences of voluntary disclosures (Healy et al., 1999; Lang and Lundholm, 1996). In addition, the study examines the effect of regulation FD on this relation. The results from the empirical analysis suggest no significant difference in the relation between conference calls and institutional ownership or analyst coverage in the post regulation FD era.

The results of this study should be interpreted with caution since the tests primarily focus on associations and there is no claim of casual direction between these relations. Even though the panel data design allows for more powerful tests, correlated omitted variables may be driving the findings of the paper. For example, if conference calls are complements to other venues of disclosure, like public financial reports or press releases then the results may be driven by those disclosures rather than conference calls per se. Also, a change in a firm's disclosure policy, analyst coverage and institutional ownership may be simultaneously driven by a change in a firm's primitive characteristics not controlled for in the paper. To mitigate this problem, we included a vast number of control variables.

Taken at face value, the empirical results presented in this study suggest that an economic benefit for firms that make extensive voluntary disclosures is the increased interest by analyst and institutional investors. Given the importance of analysts and institutions in the capital market and their significance for public firms, the study suggests that a way to attract them is by increasing the information disclosed to the market.

\section{ACKNOWLEDGEMENT}

We have benefited from useful comments and suggestions from Bipin Ajinkya, W. Robert Knechel, Gary McGill, Jason Karceski, Nikos Vafeas, Andreas Charitou and workshop participants at the University of Cyprus.

\section{AUTHOR INFORMATION}

Dr. Melita Stephanou Charitou is an Assistant Professor of Finance and Accounting, University of Nicosia, Cyprus. Dr Charitou holds a PhD in Finance and Accounting from Middlesex University, UK. She has published in various international refereed journals in Finance, Economics and Accounting. Her research interests include capital markets research, corporate finance, corporate governance and executive compensation, investments, and international financial analysis.

Dr Adamos Vlittis is an Assistant Professor of Accounting at the University of Nicosia, Cyprus. He is currently an Associate Head of the Accounting Department. He holds a PhD in Accounting from the University of Florida, USA. He has published in various international refereed journals in Accounting, Finance and Economics. His research interests include corporate governance, executive compensation, voluntary disclosure and organizational structure.

Dr Petros Lois holds an MSc degree in Accounting from De Montfort University (UK), and a PhD degree in Marine Technology from Liverpool John Moores University (UK). He holds the Chair of PricewaterhouseCoopers in Business Research at the University of Nicosia. He is currently an Associate Professor and the Head of the Accounting Department at the University of Nicosia, Cyprus. He is the Founding Editor of the "EuroMed Journal of Business" (Emerald), and a member of the editorial board of the World Journal of Business Management, and Journal "Tourism Today" (Cyprus). His research work has been published in international conference proceedings, books and journals. 


\section{REFERENCES}

1. Ackert, F., L., and Athanasakos, G., 2003. A simultaneous equations analysis of analysts' forecast bias, analyst following, and institutional ownership. Journal of Business, Finance and Accounting 30, 10171041.

2. Agrawal, A, Chadha, S., Chen, A. M., 2006. Who is afraid of Regulation FD? The behavior and performance of sell-side analysts following the SEC's fair disclosure rules. Journal of Business 79(6), 2811-2834.

3. Ajinkya, B., Bhojraj, S., Sengupta, P., 2005. The association between outside directors, institutional investors and the properties of management earnings forecasts. Journal of Accounting Research 43, 343376.

4. Akerlof, G., 1970. The market of 'lemons': quality uncertainty and the market mechanism. Quarterly Journal of Economics 90, 629-650.

5. Bamber, L., Cheon, Y., 1998. Discretionary management earnings forecast disclosures: Antecedents and outcomes associated with forecast venue and forecast specificity choices. Journal of Accounting Research 36, 167-190.

6. Barry, C.B., Brown, S.J., 1984. Differential information and the small firm effect. Journal of Financial Economics 13(2), 283-295.

7. Barry, C.B., Brown, S.J., 1985. Differential information and security market equilibrium. Journal of Financial and Quantitative Analysis 20, 407-422.

8. Bhushan, R., 1989a. Collection of information about publicly traded firms: Theory and evidence. Journal of Accounting and Economics 11, 183-207.

9. Bhushan, R., 1989b. Firm characteristics and analyst following. Journal of Accounting and Economics 11, 255-275.

10. Bowen, R., Davis, A., Matsumoto, D., 2002. Do conference calls affect analysts' forecasts? The Accounting Review 77, 285-316.

11. Brennan, M., and Hughes, P., 1991. Stock prices and the supply of information. Journal of Finance 46(5), 1665-1691.

12. Bricker, R., Grant, J., Fogarty, T., and Previts, G., 1999. Determinants of analyst following. Journal of Corporate Communications 1.

13. Brown, L.D., Higgins H.N., 2002. Managers' guidance of analysts: International evidence. Journal of Accounting and Public Policy 24(4), 280-299.

14. Brown, S., Hillegeist, A. S., and Lo, K., 2004. Conference calls and information asymmetry. Journal of Accounting and Economics 37(3), 343-366.

15. Bushee, B., 2001. Do institutional investors prefer near-term earnings over long-run value? Contemporary Accounting Research 18, 207-246.

16. Bushee, B., Noe, C., 2000. Corporate disclosure practices, institutional investors and stock return volatility. Journal of Accounting Research 38, 171-202.

17. Bushee, B., Matsumoto, D., Miller, G., 2003. Open versus closed conference calls: the determinants and effects of broadening access to disclosure. Journal of Accounting and Economics 34, 149-180.

18. Bushman, R., Chen, Q., Engel , E., Smith, A., 2004. Financial accounting information, organizational complexity and corporate governance systems. Journal of Accounting and Economics 37(2), 167-201.

19. Bushman, R., Smith, A., 2001. Financial accounting information and corporate governance. Journal of Accounting and Economics 32, 237-333.

20. Charitou A., and I. Karamanou, 2009, Bankruptcy and Managerial Opportunism: The Role of Insider Ownership Working Paper, University of Cyprus.

21. Diamond, D., Verrecchia, R., 1991. Disclosure, liquidity, and the cost of capital. Journal of Finance 46, 1325-1355.

22. Duarte, J., Han, X., Harford, J., Young, L., 2007. Information asymmetry, information dissemination and the effect of Regulation FD on the cost of capital. Journal of Financial Economics.

23. Francis, J., Hanna, J., Philbrick, D., 1998. Management communications with securities analysts. Journal of Accounting and Economics 24, 363-394.

24. Frankel, R., Johnson, M., Skinner, D., 1999. An empirical examination of conference calls as a voluntary disclosure medium. Journal of Accounting Research 37, 133-150. 
25. Fishman, M., Haggerty, K., 1989. Disclosure decisions by firms and the competition for price efficiency. Journal of Finance 44, 633-646.

26. Gintschel, A., and Markov, S., 2004. The effectiveness of regulation FD. Journal of Accounting and Economics 37, 293-314.

27. Gompers, P., Metrick, A., 1998. How are large institutions different from other investors? Why these differences matter? Working paper, Harvard Business School, 1998.

28. Greene, W., 1997. Econometric Analysis. Prentice Hall. Upper Saddle River, NJ.

29. Healy, P., Hutton, A., Palepu, K., 1999. Stock performance and intermediation changes surrounding sustained increases in disclosure. Contemporary Accounting Research 16, 485-520.

30. Healy, P., Palepu, K., 2001. Information asymmetry, corporate disclosure and the capital markets: A review of the empirical disclosure literature. Journal of Accounting and Economics 31, 405-440.

31. Heflin, F., Subramanyam, K.R., and Zhang, Y., 2003. Regulation FD and the financial information environment: Early Evidence. Accounting Review 78, 1-38

32. Holland, J., 1998. Private voluntary disclosure, financial intermediation and market efficiency. Journal of Business, Finance and Accounting 25, 29-68.

33. Karamanou, I., Vafeas, N., 2005. The association between corporate boards, audit committees, and management forecasts: An empirical analysis. Journal of Accounting Research 43, 453-486.

34. Kim, O., Verrecchia R., 1994. Market liquidity and volume around earnings announcements. Journal of Accounting and Economics 17, 41-67.

35. Lang, M., Lins, K.V., Miller, D., 2003. ADRs, analyst and accuracy. Does cross listing in the U.S. improve a firm's information environment and increase market value? Journal of Accounting Research 41(2), 317345.

36. Lang, M., Lundholm, R., 1993. Cross-sectional determinants of analysts' ratings of corporate disclosures. Journal of Accounting Research 31, 246-271.

37. Lang, M., Lundholm, R., 1996. Voluntary disclosure policy and analyst behavior. Accounting Review 71, 467-49.

38. Leuz, C., Verrecchia, R., 2000. The Economic consequences of increased disclosure. Journal of Accounting Research 38, 91-124.

39. Levitt, A. 1998. A question of integrity: promoting investor confidence by fighting insider trading. Speech given at the SEC Speaks Conference, February 1998(http://www.sec.gov/news/speech/speecharchive/1998/spch202.txt).

40. Liang, Y., Zeger, L., 1986. Longitudinal data analysis using generalized linear models. Biometrika 73, 13 22.

41. Lys, T., Soo, L., 1995. Analysts' forecast precision as a result to competitions. Journal of Accounting, Auditing and Finance 10(4), 751-765.

42. McNichols, M., Trueman, B., 1994. Public disclosure, private information collection, and short-term trading. Journal of Accounting and Economics 17, 69-94.

43. Merton, R., 1987. A simple model of capital market equilibrium with incomplete information. Journal of finance 42, 483-510.

44. O'Brien, P.C., and Bhushan, R., 1990. Analyst following and institutional ownership. Journal of Accounting research 28, 55-76.

45. Sunder, S., 2002. Investor access to conference call disclosures: Impact of regulation Fair Disclosure on information asymmetry. Working paper, New York University.

46. Tasker, S., 1998a. Bridging the information gap: Quarterly conference calls as a medium for voluntary disclosure. Review of Accounting Studies 3, 137-167.

47. Verrecchia, R., 1983. Discretionary disclosure. Journal of Accounting and Economics 5, 365-380.

\footnotetext{
${ }^{\mathrm{i}}$ Brown et al. (2004) proxy for information asymmetry using the Probalility of Informed Trade (PIN) and show that firms initiating conference calls experience long term reduction in information asymmetry.

${ }^{\text {ii }}$ We also performed the analysis using mean industry adjusted variables with qualitatively similar results.
} 


\section{NOTES}

